\title{
Çocuklarda Respiratuvar Sinsityal Virüs (RSV) Enfeksiyonlarının Tanısında Hücre Kültürü ve Direkt Floresan Antikor Testi Yöntemlerinin Karşılaştırılması
}

\author{
İmran SAĞLIK*, Derya MUTLU*, Gözde ÖNGÜT*, Sevtap VELIPAŞAOĞLU GÜNEY**, \\ Dilara ÖĞÜNÇ*, Dilek ÇOLAK
}

* Akdeniz Üniversitesi Tıp Fakültesi, Tıbbi Mikrobiyoloji Anabilim Dalı

** Akdeniz Üniversitesi Tıp Fakültesi, Çocuk Sağlı ̆̆ ve Hastalıkları Anabilim Dalı

\section{ÖZET}

Amaç: Çocukluk çağında sıklıkla görülen enfeksiyon hastalıklarından bir olan alt solunum yolu enfeksiyonlarinin (ASYE) en sik etkeni respiratuva sinsityal virüs (RSV)'tür. Bu çalışmanın amact ASYE tanısı alan 0-5 yas grubundaki çocuklarda RSV'nin hücre kültürü ve direkt floresan antikor (DFA) yöntemleri ile araştırılması ve sonuçların hastaların klinik bulguları ile birlikte değerlendirilmesidir.

Gereç ve Yöntem: ASYE tanısı alan 0-5 yaş arasındaki 107 ayaktan (poliklinik) ve 55 yatan (servis) olmak üzere 162 hasta calısmaya alınmistı. Hastaların nazofaringeal sürüntü örnekleri flocked eküvyon ile alınarak viral transport besiyeri (Copan Diagnostics, Brescia, Italya) içinde laboratuvara ulastırılmıstır. A549 hücreleri ile hazırlanan shell-vial hücre kültürlerine örnekler inoküle edilip, 48-72 saat inkübe edildikten sonra fikse edilen hücrelerde RSV varlığ floresanla ișaretli monoklonal antikorlar (Anti-RSV Group FITC, Argene, BioMérieux, Fransa) aracılığı ile araștırılmıştır. DFA yöntemi için örneklerden direkt sitospin preparatları hazırlanarak, preparatlar RSV varlığı açısından floresanla işaretli monoklonal antikorlar ile benzer şekilde incelenmistir. Hücre kültürï̈ ve DFA test sonucları uyumsuz olan örneklerde RSV RNA'sı ticari bir kit (RealStar RSV RT-PCR Kit, Altona Diagnostics, Almanya) ile gerçek zamanl polimeraz zincir reaksiyonu $(P Z R)$ yöntemi ile arasstırlmıstır. Ayrıca hastalara ait semptom, fizik muayene ve diğer laboratuvar bulgulart ile uygulanan tedaviler kaydedilmistir.

Bulgular: Incelenen 162 örne ğin 43'ünde (\%26.5) hücre kültürü ile RSV saptanmistır. Bu örneklerin 38'inde (\%24.3) hem hücre kültürü hem de DFA ile RSV saptanmıs, 115 (\%71.0) örnek her iki testle de negatif bulunmuştur. Hücre kültürrü ile pozitif olan beş örnek DFA ile negatif, DFA ile pozitif olan dört örnek hücre kültürü ile negatiftir. Bu dokuz örnekte RSV PZR testinin sonucu hücre kültürï̈ ile uyumlu bulunmuştur. Hücre kültürü̈ referans alına-

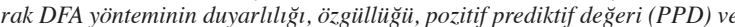
negatif prediktif değeri (NPD) strast ile \%88.4, \%96.6, \%90.5, \%95.8 olarak saptanmıştır. RSV pozitif hastaların yaş ortalaması (11.2 \pm 11.3 ay), RSV negatif saptanan hastaların yass ortalamasından (21.7 \pm 18.6 ay) anlaml olarak düsüktür $(p=0.001)$. RSV saptanan ve saptanmayan hastalar arasında cinsiyet, semptom, fizik muayene bulgulart, uygulanan tedavi ve diğer laboratuvar bulgularl (CRP, lökositoz, nötrofil yüksekliği, lenfesitoz ve trombositoz) açısından anlamlı bir fark bulunmamıstır (hepsi için $p>0.05$ ). Aylara göre test istemine bakıldığında istemlerin \%93.8'inin Ocak, Şubat ve

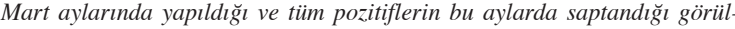
müstür.

Sonuç: Sonuç olarak bu çalışmada, ASYE olan beş yaş altındaki çocuklarda $\% 26.5$ oranında RSV saptandığ ve bu oranın erken yaslarda anlamlı olarak arttı̆̆ı görülmüştür. Virüsün tanısında DFA yöntemi yüksek duyarlılık ve özgüllü̆ge sahip olup hem hızlı tanı hem de örnek kalitesinin de ğerlendirilebilmesini sağlamaktadır.

Anahtar kelimeler: Alt solunum yolu enfeksiyonu, direkt floresan antikor hücre kültürü, $R S V$

\section{SUMMARY}

Investigation of BK and JC Virus DNA Positivities by Real-Time Polymerase Chain Reaction in Immunosuppressive Patients

Objective: Respiratory syncytial virus (RSV) is the most common cause of lower respiratory tract infections (LRTI) in children. This study was aimed to investigate the presence of RSV by cell culture and direct fluorescent antibody (DFA) methods in children with LRTI and to evaluate the results in association with the clinical findings of the patients.

\begin{abstract}
Materials and Methods: The study included 162 children with LRTI. The age group of the cases was 0-5 years old, of which 107 were outpatients and 55 were inpatients. Nasopharyngeal swab samples were obtained by flocked swabs and transported to the laboratory within the viral transport medium (Copan Diagnostics, Brescia, Italy). Samples were inoculated into the shell-vial cell culture prepared with A549 cells and presence of RSV were investigated in the fixed cells by fluorescence-labeled monoclonal antibodies (Anti-RSV Group FITC, Argene, BioMérieux, France) after 48-72 hours of incubation. For the DFA method, slides were prepared directly from the samples with cytospin centrifuge method and RSV was investigated following staining with fluorescent labeled monoclonal antibodies in a similar way. Samples which yielded discordant results with cell culture and DFA test, RSV RNA was investigated by a commercial real-time polymerase chain reaction (RT-PCR) kit (RealStar RSV RT-PCR Kit, Altona Diagnostics, Germany). In addition, symptoms, physical examination and laboratory findings together with the treatment outcome of the patients were recorded.
\end{abstract}

Results: RSV was detected in $26.5 \%$ (43/162) of the samples by cell culture Both cell culture and DFA detected RSV in 24.3\% (38/162) of the samples while $71.0 \%$ (115/162) were negative with both tests. Five RSV cell culture positive samples were negative with DFA, and four positive samples with DFA were negative with cell culture. In these nine samples, the RSV PCR test results were consistent with the cell culture test results. When the cell culture method was considered as the reference method, sensitivity, specificity, positive (PPV) and negative predictive values (NPV) for the DFA method were $88.4 \%, 96.6 \%, 90.5 \%$ and $95.8 \%$, respectively. The average age of the $R S V$-positive patients $(11.2 \pm 11.3$ months $)$ were significantly lower than that of RSV-negative patients $(21.7 \pm 18.6$ months) ( $p=0.001)$. There were no significant difference in terms of gender, symptoms, physical examination, treatment outcome and other laboratory markers (CRP, leukocytosis, increase in neutrophile count, lymphocytosis and thrombocytosis) between RSV positive and negative patients (for all $p>0.05$ ). The analysis of the RSV test requests revealed that $93.8 \%$ of the requests were in January, February and March, and all positive cases were detected in these months.

Conclusion: In conclusion, RSV was detected in $26.5 \%$ of $0-5$ years old children with LRTI and this rate was significantly higher in early ages. DFA method which has a high sensitivity and specificity in the diagnosis of RSV infection, ensures rapid diagnosis and enables the evaluation of the quality of respiratory samples.

Key words: Lower respiratory tract infections, direct fluorescent antibody test, cell culture, RSV

Alındığı tarih: 16.09 .2015

Kabul tarihi: 28.10 .2015

Yazışma adresleri: Dilek Çolak, Akdeniz Üniversitesi Tıp Fakültesi Tıbbi Mikrobiyoloji Anabilim Dalı, Antalya Tel: (0242) 2496911

e-posta: dilekc08@gmail.com 


\section{GíRiş}

Respiratuvar sinsityal virüs (RSV) kaynakl1 solunum yolu enfeksiyonları tüm dünyada çocuklarda yaygın olarak görülmektedir. RSV, çocukluk çağında görülen alt solunum yolu enfeksiyonlarının (ASYE) en sik viral etkenidir. Enfeksiyon sonrasında kalıcı immün yanıt gelişmediği için yineleyen enfeksiyonlar görülebilmektedir $^{(1-4)}$.

RSV'ye bağlı ASYE beş yaşından küçük çocuklarda yaygın olup, erken yaşlarda geçirilen enfeksiyonlarda, eşlik eden bakteriyel ve/veya viral koenfeksiyonların varlığında, immün düşkün ve kronik hastalığı olan çocuklarda klinik bulgular daha ağır seyretmekte, mortalite $\operatorname{artmaktadir}^{(5)}$. İki yaş altındaki çocukların neredeyse tümünün RSV ile karşılaştı̆̆ı ve bunların yarıya yakınında (\%40) ASYE geliştiğ bildirilmektedir $^{(2)}$. RSV ayrıca okul, kreş ve hastanelerde yenidoğan üniteleri gibi toplu yaşam alanlarında salgınlara neden olabilmektedir. $\mathrm{Bu}$ nedenle erken tanı, hem izolasyon önlemlerinin alınması hem de tedavi planlanması için önemlidir ${ }^{(6)}$.

RSV enfeksiyonlarının tanısı virüsün hücre kültüründe izolasyonu, viral antijenlerin ya da viral nükleik asitlerin saptanması gibi direkt yöntemlerle yapilmaktadir( ${ }^{(7)}$.

$\mathrm{Bu}$ çalışmanın amacı, ASYE tanısı alan çocuklarda etken olarak RSV'nin hücre kültürü ve direkt floresan antikor (DFA) yöntemleri ile araştırılması ve sonuçların hastaların klinik bulguları ile birlikte değerlendirilmesidir.

\section{GEREÇ ve YÖNTEM}

Bu çalışma Akdeniz Üniversitesi Tıp Fakültesi Klinik Araştırmalar Etik Kurulu tarafından onaylanmıştır.
Hastalar ve Örneklerin Alınması: Akdeniz Üniversitesi Hastanesi'nde 01.01.201131.03.2012 tarihleri arasında Çocuk Sağlı̆̆ı ve Hastalıkları Anabilim Dalı poliklinik (107 hasta) ve kliniklerinde (55 hasta) ASYE tanısı alan 0-5 yaş arasındaki 162 hasta çalışmaya alındı. ASYE; bronşit, bronşiolit, pnömoni ya da her üç klinik tablonun herhangi iki bileşeninin olması olarak tanımland $1^{(8)}$.

Hasta yakınlarından onam alındıktan sonra, hastaların nazofaringeal sürüntü örnekleri flocked eküvyon (Copan Diagnostics, Brescia, İtalya) ile alınarak, viral taşıma besiyeri (VTB) içeren tüp (Copan Diagnostics, Brescia, İtalya) içine konuldu ve bekletilmeden testlerin yapılacağ laboratuvara ulaştırıldı. Hastalara ait semptom ve fizik muayene (öksürük, ateş (koltuk altı: $>37^{\circ} \mathrm{C}$ ), takipne, hirıltılı solunum, farenjit, tonsillit, akciğer oskültasyon bulguları), laboratuvar (lökosit, nötrofil, lenfosit, trombosit sayıları ve CRP düzeyleri), radyoloji (akciğer grafisi değerlendirmesi) bulguları ile uygulanan tedaviler kaydedildi.

Virolojik testler: Hastalardan alınan ve VTB içeren tüpler içine konan örnekler Akdeniz Üniversitesi Hastanesi Merkez Laboratuvarı Mikrobiyoloji Bölümü'ne ulaştırıldı ve virolojik testler bu bölümün laboratuvarında gerçekleştirildi. Öncelikle örnek içeren VTB tüpleri laboratuvara ulaştı $\breve{g}_{1}$ anda vortekslenerek eküvyon atıld $1 ;+4^{\circ} \mathrm{C}^{\prime}$ de saklanan örnekler 48 saat içinde DFA testi ve hücre kültürü için hazırlandı.

Hücre kültürü olarak shell vial hücre kültürü yöntemi uygulandı ve A549 hücreleri ile \%10 fetal dana serumu (Sigma, Almanya), \%2 L-glutamin (Sigma, Almanya), \%1 HEPES (Sigma, Almanya), \%1 penisilin-streptomisin (Sigma, Almanya), \%0.1 gentamisin (Sigma, Almanya) ve \%0.4 amfoterisin-B (Sigma, Almanya) içeren Dulbecco'nun Modifiye Eagle 
Besiyeri (Sigma, Almanya) kullanıldı. VTB'ler $1000 \mathrm{~g}$ hızda beş dakika santrifüj (Eppendorf Centrifuge $5804 \mathrm{R}$, Almanya) edildikten sonra $300 \mu 1$ örnek, A549 hücreleri ile kaplı viale inoküle edildi. Vialler 700 g'de oda isısında bir saat santrifüj edildi, ardından $\% 5 \mathrm{CO}_{2}$ içeren $37^{\circ} \mathrm{C}$ inkübatörde nemli ortamda bir saat bekletildi ve her viale besiyeri eklendi. Vialler $37^{\circ} \mathrm{C}$ ' de $\% 5 \mathrm{CO}_{2}$ içeren nemli ortamda $48-72$ saat inkübe edildi. Hücreler asetonla fikse edilerek, RSV monoklonal antikorları (AntiRSV Group FITC, Argene, BioMérieux, Fransa) ile üretici firmanın önerileri doğrultusunda boyand1. Hazirlanan preparatlar floresan mikroskopta (Olympus BX50, Japonya) x20 ve x40 büyütmede değerlendirildi; RSV'ye özgü sitoplazmik flöresan boyanma gösteren en az iki hücre varlığı pozitif olarak kabul edildi (Resim 1).

DFA testi için, VTB içeren tüpler $400 \mathrm{~g}$ hızda $4{ }^{\circ} \mathrm{C}$ 'de 10 dakika santrifüj (Eppendorf Centrifuge 5804 R, Almanya) edildikten sonra dibe çöken kısmından $80 \mu 1$ alınarak sitosantrifüjde (Thermo Electron Corporation Cytospin 4, ABD) $800 \mathrm{rpm}$ hızda 3 dakika çevrilerek sitospin yayması hazırland. Yaymalar asetonla fikse edildi ve RSV monoklonal antikorları (Anti-RSV Group FITC, Argene, BioMérieux,

Fransa) ile üretici firmanın önerileri doğrultusunda boyand1. Hazırlanan preparatlar floresan mikroskopta (Olympus BX50, Japonya) x20 ve x40 büyütmede pozitif ve negatif kontrol yaymaları ile birlikte değerlendirildi. Sitoplazmasında parlak granüler floresan veren en az iki intakt epitel hücresi varlığı pozitif olarak kabul edildi (Resim 2).

Hücre kültürü ve DFA testi sonuçları uyumsuz olan örneklerde gerçek zamanlı polimeraz zincir reaksiyonu (PZR) testi ile RSV RNA's1 araştırıldı. RNA ekstraksiyonu ticari bir kit (EZ1 Virus Mini Kit v2.0, Qiagen, Almanya) ile yapıldıktan sonra yine ticari bir kit (RealStar RSV RT-PCR Kit, Altona Diagnostics, Almanya) ile RSV RNA's1 Rotor-Gene (Q5/6 plex Platform, Qiagen, Almanya) cihazı kullanılarak araştırıldı.

İstatistiksel Analiz: İstatistiksel veri analizi için Statistical Package for the Social Sciences (SPSS version 16.0; SPSS Inc., Chicago, IL, USA) programı kullanıldı. Veriler arasında karşılaştırma yaparken Mann-Whitney U, Pearson ChiSquare ve Fisher's Exact testlerinden yararlanıldı. p değeri <0.05 olan sonuçlar anlamlı kabul edildi.

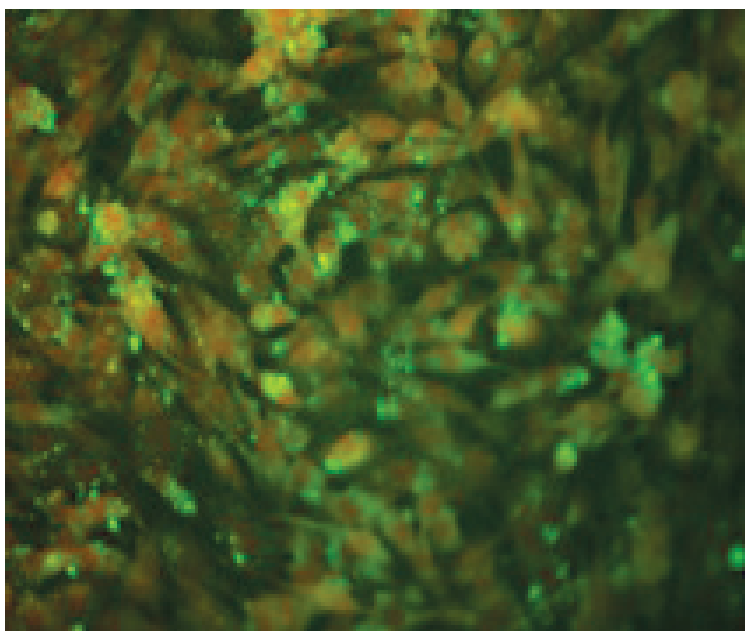

Resim 1. Solda: Ekim yapılmamış A549 hücreleri (x20). Sağda: A549 hücrelerinde RSV varlığının FITC ile işaretli monoklonal antikorla boyanarak gösterilmesi (x20). 

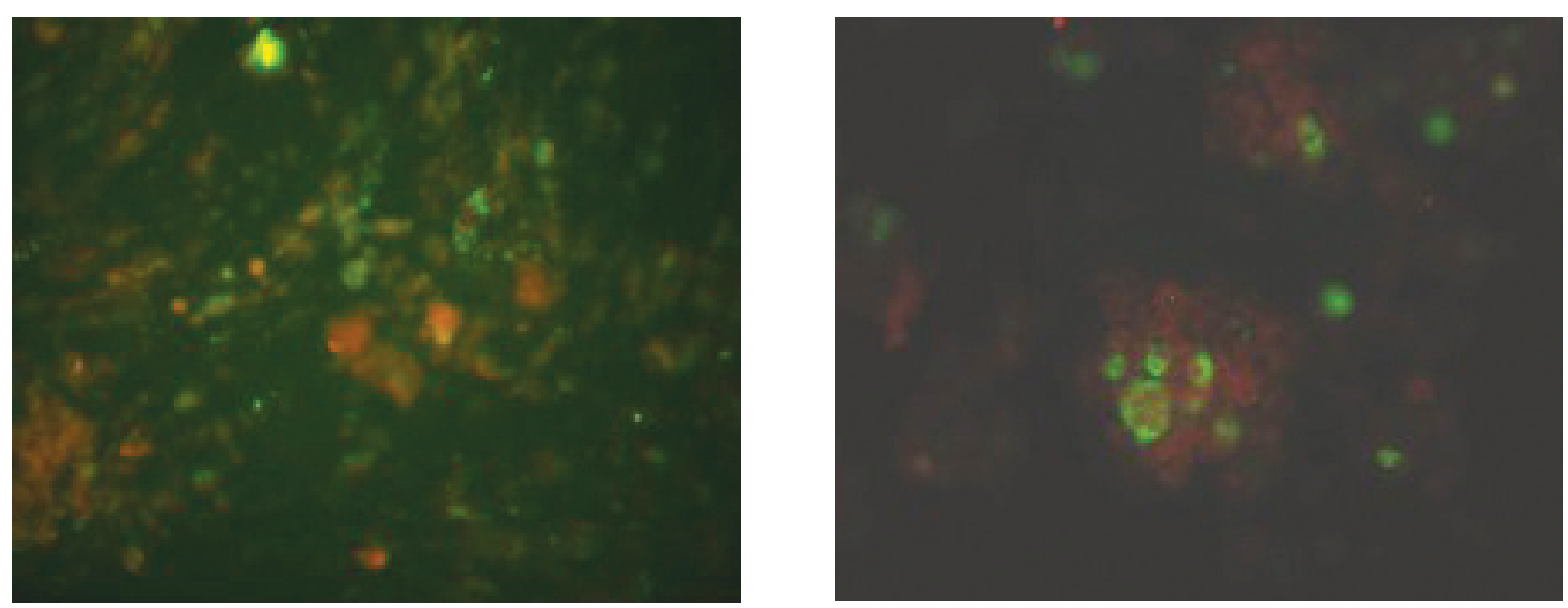

Resim 2. Nazofarengeal sürüntï örneğinde DFA ile RSV antijen pozitifliği (Solda: x20, Sağda: x40).

\section{BULGULAR}

İncelenen 162 örneğin 43'ünde (\%26.5) hücre kültürü ile RSV saptanmıştır. Bu örneklerin 38 'inde (\%24.3) hem hücre kültürü hem de DFA ile RSV saptanmış, 115 (\%71.0) örnek her iki testle de negatif bulunmuştur (Tablo 1). Hücre kültürü ile pozitif olan beş örnek DFA ile negatif, DFA ile pozitif olan dört örnek hücre kültürü ile negatifdir. Bu dokuz örnekte RSV PZR testinin sonucu hücre kültürü ile uyumlu bulunmuştur. Hücre kültürü referans alınarak DFA yönteminin duyarlılı̆̆ 1 , özgüllü̆ğü, pozitif prediktif değeri (PPD) ve negatif prediktif değeri (NPD) sirasi ile \%88.4, \%96.6, \%90.5, \%95.8 olarak saptanmıştır.

Tablo 1. Direkt floresan antikor (DFA) testinin hücre kültürüyle karşılaştırılması.

\begin{tabular}{ccccc}
\hline & & \multicolumn{2}{c}{ Hücre Kültürü } & \\
\cline { 3 - 4 } & & Pozitif & Negatif & Toplam \\
\hline \multirow{2}{*}{ DFA } & Pozitif & 38 & 4 & 42 \\
& Negatif & 5 & 115 & 120 \\
& Toplam & 43 & 119 & 162 \\
\hline
\end{tabular}

Duyarlılık \%88.4, ̈̈zgüllük \%96.6, Pozitif prediktif değeri \%90.5, negatif prediktif değeri $\% 95.8$

ASYE tanısı ile çalışmamıza alınan hastaların demografik bilgileri ve kronik hastalık varlığ Tablo 2'de belirtilmiştir. Yüz altmış iki çocuğun 87'si <1 yaş, 39'u 1-2 yaş ve 36's1 >2 yaş grubundayd1. RSV pozitifliği $<1,1-2$ ve $>2$ yaş aralıklarında sirası ile \%34.5 (30/87), \%28.2 (11/39) ve \%5.5 (2/36) olarak bulunmuştur. RSV pozitif hastaların yaş ortalaması (11.2 $\pm 11.3 \mathrm{ay})$, RSV negatif saptanan hastaların yaş ortalama-

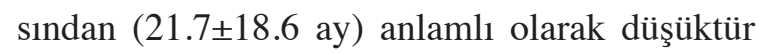
$(p=0.001)$. RSV pozitifliğinin cinsiyetle bir ilişkisi saptanmamıştır $(\mathrm{p}=0.2)$.

Tablo 2. Hastaların demografik bilgileri ve eşlik eden kronik hastalık varlığı.

\begin{tabular}{lcccc}
\hline Özellik & $\begin{array}{c}\text { Toplam } \\
(\mathbf{\%})\end{array}$ & $\begin{array}{c}\text { RSV negatif } \\
(\mathbf{\%})\end{array}$ & $\begin{array}{c}\text { RSV pozitif } \\
(\mathbf{\%})\end{array}$ & p \\
\hline & & $\mathbf{1 1 9}(\mathbf{7 3 . 4 )}$ & $\mathbf{4 3 ( 2 6 . 5 )}$ & \\
\hline $\begin{array}{l}\text { Ortalama yaş (ay) } \\
\text { Cinsiyet }\end{array}$ & $18.9 \pm 17.5$ & $21.7 \pm 18.6$ & $11.2 \pm 11.3$ & 0.001 \\
$\quad$ Erkek & $91(56.2)$ & $70(58.8)$ & $21(48.8)$ & 0.2 \\
$\quad$ Kadın & $71(43.8)$ & $49(41.2)$ & $22(51.2)$ & 0.2 \\
Kronik hastalık varlığı & $59(36.4)$ & $50(42.0)$ & $9(20.9)$ & 0.01 \\
\hline
\end{tabular}

Yatarak veya ayakta tedavi edilen klinik veya poliklinik hastalarında RSV pozitifliği açısından anlamlı bir fark saptanmamıştır [sırası ile \%29.1 $(16 / 55)$ ve \%25.3 (27/107)].

Oskültasyonda ral, ronküs şeklinde patolojik akciğer dinleme bulgusu RSV pozitif hastalarda anlamlı olarak daha fazla olmasına karşın (\%81.4 ve \%52.9, p=0.001), akciğer grafisinde patolojik görünüm açısından bir fark gözlenmemiştir $(p=0.49)$. Benzer şekilde öksürük, faranjit, 
tonsilit, takipne, hırıltılı solunum ve ateş varlığ açısından da iki grup arasında anlamlı fark saptanmamıştır.

RSV pozitif ve negatif hastaların tedavisinde antibiyotik [\%48.8 ve \%52.1; $(\mathrm{p}=0.71)]$, bronkodilatatör [\%83.7 ve \%79.8 $(\mathrm{p}=0.57)]$, inhaler formda beta adrenerjik agonist [\%46.5 ve \%38.7 $(\mathrm{p}=0.37)]$ ve inhaler formda steroid [\%30.2 ve \%46.2 ( $\mathrm{p=0.07)]} \mathrm{kullanımı} \mathrm{açısından} \mathrm{gruplar}$ arasında bir fark saptanmamıştır.

RSV pozitif hastaların \%72.1'inin bronşitbronşiolit, \%27.9'unun pnömoni, RSV negatif hastaların ise \%81.5'inin bronşit-bronşiolit, $\% 18.5$ 'inin pnömoni tanısı almış olduğu görülmüş, ancak arada anlamlı bir fark saptanmamış$\operatorname{tir}(\mathrm{p}=0.2)$.

RSV pozitif ve negatif hastalarda CRP değerleri, lökositoz, nötrofil yüksekliği, lenfositoz ve trombositoz sirasi ile \%64.0 ve \%66.7 ( $\mathrm{p}=0.81)$, $\% 15.4$ ve \%24.6 ( $\mathrm{p}=0.82), \% 42.3$ ve \%55.4 $(\mathrm{p}=0.97), \% 69.2$ ve $\% 56.9(\mathrm{p}=0.31), \% 19.2$ ve $\% 32.3(\mathrm{p}=0.62)$ oranlarında bulunmuştur.

Aylara göre test istemine bakıldığında, istemlerin \%93.8'inin Ocak, Şubat ve Mart aylarında yapıldığ 1 ve tüm pozitiflerin bu aylarda saptandığ 1 görülmüştür.

\section{TARTIŞMA}

Bu çalışmada, ASYE tanısı alan 0-5 yaş aralığındaki çocuklarda RSV'nin görülme sıklığ 1 \%26.5 olarak bulunmuş ve virüs erken yaş gruplarında (RSV pozitif hastaların yaş ortalaması: 11.2 \pm 11.3 ay, RSV negatif saptanan hastaların yaş ortalaması: $21.7 \pm 18.6$ ay; $p=0.001$ ) daha sık saptanmıştır. DFA testi, direkt tanıda hızlı ve güvenilir bir yöntem olarak bulunmuştur.

ASYE tanısı alan beş yaşın altındaki çocuklarda yapılan çalışmalarda; ABD'de \%20.0 ${ }^{(9)}$, Mısır'da
$\% 23.7^{(10)}$, İngiltere'de $\% 17.5^{(11)}$, Brezilya'da $\% 28.0^{(12)} \mathrm{RSV}$ pozitifliği bildirilmiștir. Ülkemizde ise, Aydın'da ASYE nedeniyle hastanede yatan 0-18 yaş grubundaki çocuklarda $\% 10.3^{(13)}$, İstanbul'da 9 yaş altında solunum yolu enfeksiyonu nedeniyle hastaneye yatan çocuklarda $\% 32.0^{(14)} \mathrm{RSV}$ pozitifliği bildirilmiştir.

RSV'ye bağlı ASYE'ler erken yaşlarda daha sık görülür ve genellikle iyi seyirlidir ${ }^{(15)}$. Ancak 2 yaşından önce geçirilen (özellikle prematüre bebeklerde) ve yineleyen enfeksiyonlarda hastalık, daha ağır seyretmekte ve hastaların hastaneye yatış oranları $\operatorname{artmaktadır}^{(2)}$. Ayrıca bu tür enfeksiyonlar, hastalarda astım ve hışıltı atakları gibi ciddi ve kalıcı obstrüktif akciğer hastalıklarına yol açabilir ${ }^{(16,17)}$. Bu nedenle viral etiyolojinin belirlenmesi, prognozun tahmin edilmesi ve gerekli durumlarda tedavinin planlanmasına (örneğin, ribavirin, RSV spesifik antikor) yardımcıdır. Sunulan çalışmada RSV pozitifliği saptanan hastaların yaş ortalaması RSV negatif hastalardan daha düşük bulunmuştur. Çalışmamızda iki yaş ve altındaki çocuklarda \%32.5 oranında RSV pozitifliği saptanmış olup, ülkemizde yapılan diğer çalışmalarda da benzer şekilde, ASYE olan iki yaş altındaki çocuklarda İstanbul'da \% 35.0 ${ }^{(18)}$ Bursa'da \% $37.9^{(16)}$, Ankara'da ise \% 44.4 ${ }^{(19)}$; bronşiolit tanısı olan iki yaş altındaki çocuklarda İstanbul'da \%20.0(20), Mersin'de ${ }^{(21)} \% 33.9$ RSV pozitifliği bildirilmiştir.

RSV enfeksiyonlarının görülme sıklığı mevsimsel olarak değişkenlik göstermektedir ve özellikle kış ve ilkbahar aylarında yüksektir ${ }^{(16)}$. Türk Neonatoloji Derneği tarafından yapılan çok merkezli bir çalışma Ocak ve Mart aylarında RSV sıklığının arttı̆̆ı bildirilmişş(15), bir başka çalışmada ise bağıl nem artışının ve soğuk havayla birlikte kapalı yaşam alanlarının artmasının, duyarlı nüfusun varlığı ile birlikte RSV enfeksiyonlarını tetikleyebileceği öne sürülmüştür ${ }^{(14,15)}$. Çalışmamızda da benzer şekilde, tüm pozitif örnekler Ocak, Şubat ve Mart aylarında saptan- 
mıştır. Bu nedenle, RSV pozitifliğinin, çalışmanın kapsadığı mevsimlere bağlı olarak değişebileceği unutulmamalıdır.

RSV enfeksiyonlarının tanısında hücre kültürü altın standart olmakla birlikte, yöntemin zaman alıcı ve yorucu olması, DFA ve PZR gibi hızlı testlerin tanıda yaygın olarak kullanılmasına neden olmuştur ${ }^{(4)}$. Çalışmamızda shell vial hücre kültürü yöntemi uygulanmıştır. Shell vial yöntemi ile virüs izolasyonu klasik hücre kültüründeki gibi sitopatik etkinin oluşması beklenmediği için daha erken tanı sağlamakta, üstelik floresan işaretli monoklonal antikorların kullanılması virüsün tanımlanmasını kolaylaştırmaktadır. Yöntemin başarısı için uygun hasta ve örnek seçimi, örneğin miktarının yeterli olması ve uygun koşullarda alınması, virüsün canlılığını koruyarak laboratuvara taşınması ve çalışılması çok önemlidir. RSV'nin çevre koşullarına dayanıksız olması, hücre kültürü çalışmalarında karşılaşılan önemli bir sorundur, ancak hücre kültürleri virüsün elde edilmesine ve ileri çalışmalara olanak sağlamaktadır(22).

Tanıda kullanılan bir diğer test olan DFA, hücre kültürüne göre uygulanması daha kolay bir yöntemdir ve DFA ile RSV antijenlerinin saptanmas1, kısa sürede sonuç vermesi ve duyarlılığının yüksek olması nedeniyle, başarılı bir yöntem olarak bildirilmiştir ${ }^{(4,23-25)}$.

RSV tanısına yönelik olarak Jacobsen ve ark. ${ }^{(26)}$ 880 örneği içeren çalışmalarında DFA yöntemini hücre kültürü ile karşılaştırmışlar ve sırası ile testin duyarlılık, özgüllük, PPD ve NPD'sini $\% 0.95, \% 0.91 \% 0.82$ ve \%0.98 olarak bulmuşlardır. Ülkemizde ise Gökalp ve ark. ${ }^{(22)}$ RSV tanısında hücre kültürü ile karşılaştırdıkları DFA yönteminin duyarlılık, özgüllük, $P P D$ ve NPD'lerini \%100.0, \%85.7, \%65.4 ve \% 100.0 olarak bildirmişlerdir. Shafik ve ark. ${ }^{(10)}$ ise RSV tanısında GZ-PZR ile DFA'yı karşılaştırmışlar ve testin duyarlılığının enfeksiyonun ilk üç gününde yüksek (\%86) olduğunu, ancak sonraki günlerde bu oranın \%65'e kadar düştügüünü; özgüllü̈̆ünün ise değişmediğini (\%99 ile \%100) bildirmişlerdir. Çalışmamızda da benzer şekilde, DFA testinin duyarlılığı, özgüllüŭgü, PPD ve NPD'si sirasiyla \%88.4, \%96.6, \%90.5, \%95.8 olarak bulunmuştur. DFA ve hücre kültürü testlerinin uyumsuz sonuç verdiği dokuz örnek GZ-PZR ile çalışıldığında, sonuçlar hücre kültürü testinin sonuçları ile uyumlu bulunmuştur. Abu-Diab ve ark. ${ }^{(27)}$ çalışmalarında benzer şekilde DFA ile negatif olan örnekleri GZ-PZR ile pozitif bulmuşlar, flock swab ile alınan örneklerin, DFA ile saptanabilecek kadar RSV ile enfekte epitel hücresi içermediğini ancak, daha duyar11 yöntem olan GZ-PZR ile saptanabilecek kadar serbest virüs içerdiğini öne sürmüşlerdir. $\mathrm{Bu}$ çalışmada, benzer şekilde GZ-PZR ve hücre kültürü ile saptanan ancak DFA ile saptanamayan beş örneğin, DFA ile saptanabilecek miktarda enfekte epitel hücresi içermediğini, ancak serbest virüs miktarının diğer iki testle saptanabilecek düzeyde olduğunu düşündük. PZR testlerindeki gelişmeler son yıllarda solunum yolu virüslerinin hizlı tanısinda bu testlerin tercih edilmesine neden olmuştur. Ancak bu testlerin maliyeti yüksektir ve her merkezde uygun laboratuvar koşulları sağlanamamaktadır. DFA duyarlılı̆̆ı ve özgüllüğ̈̈ yüksek, hızlı ve nispeten kolay bir yöntemdir ve RSV hızlı tanısında yerini korumaktadir $\mathrm{r}^{(10,17,22,26)}$.

Tartışılması gereken bir diğer konu ASYE tan1sında yeterli miktarda epitel hücresi içeren kaliteli örnek alınmasıdır ki, uygulanan tanı testinin başarısını direkt olarak etkilemektedir. Örnek alımında esnek flocked eküvyonlar RSV izolasyonunda duyarlı (\%89-100) bulunmuş, ayrica hasta uyumunu da kolaylaştırdığ 1 bildirilmiştir ${ }^{(27-29)}$. Bu çalışmada da kullanılan esnek flocked eküvyonların çocuk hastalardan örneğin alınmasını, taşınmasını ve saklanmasını kolaylaştırdı $\breve{g} 1$ görülmüsstür. Ayrıca DFA testi ile örneğin değerlendirilmesi sırasında yeterli epitel içerip 
içermediği değerlendirilebilmektedir.

Hastalarda eşlik eden kronik hastalıkların varlığının (konjenital kalp hastalığı gibi) RSV enfeksiyonlarının epidemiyolojik olarak sıklığını arttırmadı $\breve{g} 1$, ancak hastalığın ciddiyetini ve mortalitesini arttırdı ğıbildirilmiştir ${ }^{(30,31)}$.Çalışmamızda, RSV negatif hastalarda eşlik eden kronik hastalıkların daha çok olduğu görülmüş ve benzer şekilde, eşlik eden kronik hastalıkların RSV enfeksiyonlarının sıklığını arttırmadığı saptanmıştır. Ancak hastaların klinik durumları takip edilmemiştir.

Bu çalışmada, ASYE olan RSV pozitif ve negatif hastalarda, CRP düzeyi, lenfosit, lökosit, trombosit ve nötrofil miktarları karşılaştırılmış ve anlamlı fark olmadı $\breve{g}_{1}$ bulunmuştur $(\mathrm{p}>0.05)$. Kayıran ve ark. ${ }^{(20)}$ çalışmalarında, RSV'ye bağlı bronşioliti olan çocuklarda benzer şekilde ateş, lökosit sayısı, CRP değerleri ve hastaneye yatış oranları açısından fark bulamamışlardır.

Sonuç olarak, bu çalışmada, ASYE olan beş yaş altındaki çocuklarda \%26.5 oranında RSV saptandığ 1 ve bu oranın erken yaşlarda anlamlı olarak attığg görülmüsstür. Virüsün tanısında DFA yöntemi, yüksek duyarlılık ve özgüllüŭge sahip olup, hem hızlı tanı hem de örnek kalitesinin değerlendirilebilmesini sağlamaktadır.

\section{KAYNAKLAR}

1. Haynes AK, Manangan AP, Iwane MK, et al. Respiratory syncytial virus circulation in seven countries with Global Disease Detection Regional Centers. J Infect Dis 2013; 208(Suppl 3):S246-54. http://dx.doi.org/10.1093/infdis/jit515

2. Wright M, Piedimonte G. Respiratory syncytial virus prevention and therapy: past, present, and future. Pediatr Pulmonol 2011; 46:324-47. http://dx.doi.org/10.1002/ppul.21377

3. Boyer KM, Jacobson PA. Viral and atypical pneumonia. Philadelphia: Lippincott Williams\&Wilkins; 2006: 408-11.

4. Ostlund MR, Wirgart BZ, Linde A, Grillner L. Respiratory virus infections in Stockholm during seven seasons: a retrospective study of laboratory diagnosis. Scand J Infect Dis 2004; 36:460-5. http://dx.doi.org/10.1080/00365540410015295

5. Naorat $S$, Chittaganpitch $M$, Thamthitiwat $S$, et al. Hospitalizations for acute lower respiratory tract infection due to respiratory syncytial virus in Thailand, 2008-2011. J Infect Dis 2013; 208(Suppl 3):S238-45. http://dx.doi.org/10.1093/infdis/jit456

6. Kumar P, McKean MC. Evidence based paediatrics: review of BTS guidelines for the management of community acquired pneumonia in children. $J$ Infect 2004; 48:134-8. http://dx.doi.org/10.1016/j.jinf.2003.10.013

7. Puppe W, Weigl JA, Aron G, et al. Evaluation of a multiplex reverse transcriptase PCR ELISA for the detection of nine respiratory tract pathogens. J Clin Virol 2004; 30:165-74. http://dx.doi.org/10.1016/j.jcv.2003.10.003

8. Kocabaş E, Doğru Ersöz D, Karakoç F, et al. Türk Toraks Derneği çocuklarda toplumda gelişen pnömoni tanı ve tedavi uzlaşı raporu. Türk Toraks Dergisi 2009; 10(Ek3).

9. Iwane MK, Edwards KM, Szilagyi PG, et al. Population-based surveillance for hospitalizations associated with respiratory syncytial virus, influenza virus, and parainfluenza viruses among young children. Pediatrics 2004; 113:1758-64 http://dx.doi.org/10.1542/peds.113.6.1758

10. Shafik CF, Mohareb EW, Youssef FG. Comparison of direct fluorescence assay and real-time rt-PCR as diagnostics for respiratory syncytial virus in young children. J Trop Med 2011; 2011:781919. http://dx.doi.org/10.1155/2011/781919

11. Müller-Pebody B, Edmunds WJ, Zambon MC, Gay NJ, Crowcroft NS. Contribution of RSV to bronchiolitis and pneumonia-associated hospitalizations in English children, April 1995-March 1998. Epidemiol Infect 2002; 129:99-106. http://dx.doi.org/10.1017/s095026880200729x

12. Pecchini R, Berezin EN, Felicio MC, et al. Incidence and clinical characteristics of the infection by the respiratory syncytial virus in children admitted in Santa Casa de São Paulo Hospital. Braz J Infect Dis 2008; 12:476-9. http://dx.doi.org/10.1590/S1413-86702008000600006

13. Sancaklı Ö, Yenigün A, Kırdar S. Alt solunum yolu enfeksiyonunda nazofaringeal örneklerde polimeraz zincir reaksiyonu sonuçları. J Pediatr Inf 2012; $6: 84-9$

http://dx.doi.org/10.5152/ced .2012 .26

14. Bicer S, Giray T, Çöl D, et al. Virological and clinical characterizations of respiratory infections in hospitalized children. Ital J Pediatr 2013; 39:22. http://dx.doi.org/10.1186/1824-7288-39-22

15. Türk Neonatoloji Derneği Respiratuar Sinsityal Virüs Enfeksiyonları Çalışma Grubu. Türkiye'de respiratuvar sinsityal virüs enfeksiyonlarının mevsimsel özellikleri: iki yıllık epidemiyoloji çalışması. Çocuk Să̆lı̆̆ ve Hastalıkları Dergisi 2012; 55:1-8.

16. Hacimustafaoglu M, Celebi S, Bozdemir SE, et al. RSV frequency in children below 2 years hospitalized for lower respiratory tract infections. Turk $J$ Pediatr 2013; 55:130-9.

17. Hacımustafaoğlu M. RSV İnfeksiyonları. ANKEM Derg 2006; 20(Ek 2):E240-7.

18. Yilmaz G, Uzel N, Isik N, Baysal SU, Aslan S, Badur 
S. Viral lower respiratory tract infections in children in Istanbul, Turkey. Pediatr Infect Dis J 1999; 18:173. http://dx.doi.org/10.1097/00006454-199902000-00022

19. Tanır G, Doğru Ü, Uzunali Ö, Akar N. Viral alt solunum yolu enfeksiyonu bulguları olan bebeklerde Respiratory Sinsityal Virus (RSV) enfeksiyonlarının sıklığı ve klinik özellikleri. Türkiye Klinikleri J Pediatr 2000; 9:93-7.

20. Kayıran SM, Paloğlu E, Gürakan B. Bronşiyolit tanısıyla izlenen küçük çocuklarda RSV sıklığı, klinik ve laboratuvar özellikleri. Turk Pediatri Ars 2010; 45:252-6. http://dx.doi.org/10.4274/tpa.45.252

21. Uyar M, Kuyucu N, Tezcan S, Aslan G, Tasdelen B. Bronşiyolit tanısı alan 0-2 yaş grubu çocuklarda insan bokavirus ve diğer solunum viruslarının sıklığının araştırılması. Mikrobiyol Bul 2014; 48:242-58. http://dx.doi.org/10.5578/mb.7575

22. Gokalp C, Gokahmetoglu S, Saatci Deniz ES, Gunes T. Alt solunum yolu enfeksiyonu olan çocuklarda solunum sinsityal virus varlığının üç farklı yöntemle araştırılması. Mikrobiyol Bul 2009; 43:433-8.

23. Landry ML, Ferguson D. SimulFluor respiratory screen for rapid detection of multiple respiratory viruses in clinical specimens by immunofluorescence staining. J Clin Microbiol 2000; 38:708-11.

24. Gregson D, Lloyd T, Buchan S, Church D. Comparison of the RSV respi-strip with direct fluorescent-antigen detection for diagnosis of respiratory syncytial virus infection in pediatric patients. J Clin Microbiol 2005; 43:5782-3. http://dx.doi.org/10.1128/JCM.43.11.5782-5783.2005

25. Henrickson KJ, Hall CB. Diagnostic assays for respiratory syncytial virus disease. Pediatr Infect Dis $J$ 2007; 26(11 Suppl):S36-40.
http://dx.doi.org/10.1097/INF.0b013e318157da6f

26. Jacobsen D, Ackerman P, Payne NR. Rapid identification of respiratory syncytial virus infections by direct fluorescent antibody testing: reliability as a guide to patient cohorting. Am J Infect Control 1991; 19:73-8. http://dx.doi.org/10.1016/0196-6553(91)90042-B

27. Abu-Diab A, Azzeh M, Ghneim R, et al. Comparison between pernasal flocked swabs and nasopharyngeal aspirates for detection of common respiratory viruses in samples from children. J Clin Microbiol 2008; 46:2414-7. http://dx.doi.org/10.1128/JCM.00369-08

28. Walsh P, Nguyen TA, Higashida K, et al. Do infants and toddlers prefer nasal swabs or washes for specimen collection? Pediatr Infect Dis J 2010; 29:1156-7. http://dx.doi.org/10.1097/INF.0b013e3181fb45ae

29. Debyle C, Bulkow L, Miernyk K, et al. Comparison of nasopharyngeal flocked swabs and nasopharyngeal wash collection methods for respiratory virus detection in hospitalized children using real-time polymerase chain reaction. $J$ Virol Methods 2012; 185:89-93. http://dx.doi.org/10.1016/j.jviromet.2012.06.009

30. Thorburn K. Pre-existing disease is associated with a significantly higher risk of death in severe respiratory syncytial virus infection. Arch Dis Child 2009; 94:99103. http://dx.doi.org/10.1136/adc.2008.139188

31. Rowlinson E, Dueger E, Taylor T, et al. Incidence and clinical features of respiratory syncytial virus infections in a population-based surveillance site in the Nile Delta Region. J Infect Dis 2013; 208(Suppl 3):S189-96.

http://dx.doi.org/10.1093/infdis/jit457 